\title{
The significance and clinical utility of the detection of primary malignant circulating prostate cells: a review of the evidence
}

\author{
Nigel P. Murray ${ }^{1,2}$ \\ ${ }^{1}$ Hospital Carabineros of Chile, Nunoa, 7770199 Santiago, Chile. \\ ${ }^{2}$ Faculty of Medicine, University Finis Terrae, Providencia, 7501015 Santiago, Chile.
}

Correspondence to: Dr. Nigel P. Murray, Faculty of Medicine, University Finis Terrae, Providencia, 7501015 Santiago, Chile.

E-mail: nigelpetermurray@gmail.com

How to cite this article: Murray NP. The significance and clinical utility of the detection of primary malignant circulating prostate cells: a review of the evidence. J Cancer Metastasis Treat 2016;2:453-62.

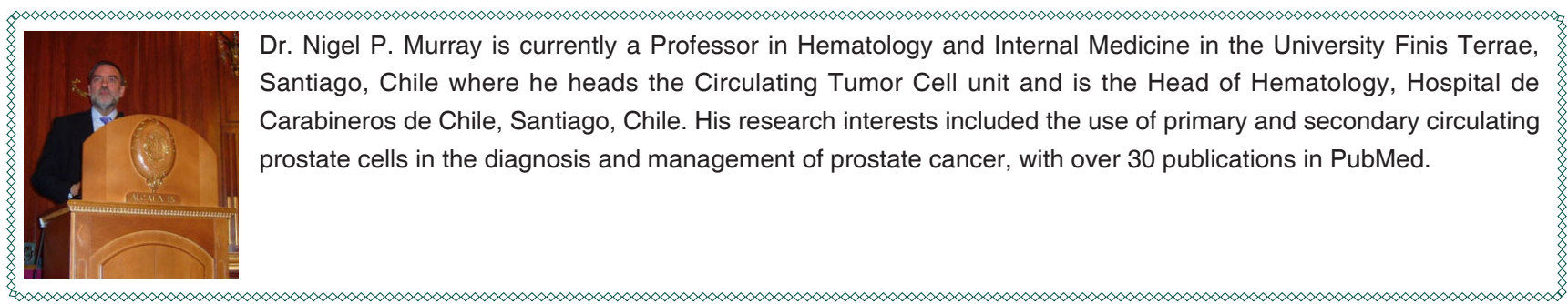

Article history:

Received: 21-09-2016

Accepted: 01-12-2016

Published: 16-12-2016

Key words:

Prostate cancer,

circulating prostate cells,

cancer detection,

prognostic factor

\section{ABSTRACT}

Primary malignant circulating prostate cells (CPCs) are those detected in blood before definitive treatment for prostate cancer. CPCs can be detected in men with benign prostate disease; however, some methods to distinguish between benign and malignant prostate cells have to be validated. This study presents a review of the subject, including theoretical considerations for the selection of markers to detect them, the different methods used, and the utility of their detection in identifying men with prostate cancer and as a prognostic factor.

\section{INTRODUCTION}

Prostate cancer is the most common tumor diagnosed in men in the Western world. With demographic changes and the aging population, the number of men with this cancer has steadily increased. The natural history of untreated prostate cancer is one of evolution to a metastatic disease, especially disseminating to

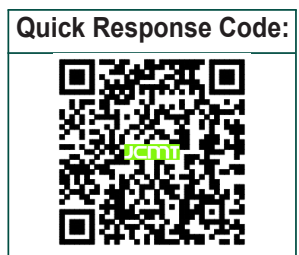


bone, over a variable time period.

Two large questions have yet to be answered: (1) what is the role of prostate cancer screening? (2) what treatment is appropriate for men diagnosed with prostate cancer? An ideal prostate cancer screening test would not detect all prostate cancers, but only those prostate cancers which have the potential to cause harm to the patient. At present, the only widely used screening test is serum total prostate-specific antigen (PSA), which in a range of $4-10 \mathrm{ng} / \mathrm{mL}$ is associated with a positive biopsy rate for all cancers of approximately $30 \% .{ }^{[1]}$ of which it has been estimated that $23-42 \%$ of screen detected prostate cancers are over treated. ${ }^{[2]}$ Men with clinically insignificant prostate cancers who were never destined to have symptoms or altered life expectancy may not benefit from knowing that they have the "disease." The detection of clinically insignificant prostate cancer may be considered an adverse effect of the prostate biopsy.

Screening for prostate cancer remains controversial. The two large studies published in the United States and Europe produced different results; ${ }^{[3,4]}$ as a consequence, the American Urology Association guidelines do not recommend screening in men over 70 years or in those with less than 10 years' life expectancy. ${ }^{[5]}$ However, they recognize that some elderly men who are healthy may benefit from screening. Why the controversy? Presently, a new diagnosis of prostate cancer is nearly always in men with an elevated screening serum total PSA who have been referred for a prostate biopsy. Serum total PSA is prostate specific. However, it is also increased in benign diseases such as hyperplasia and prostatitis. ${ }^{[4,5]}$ In fact, $10-20 \%$ of men aged 50 years and 70 years will have a raised PSA, but only $25 \%$ of those with a serum total PSA of $4-10 \mathrm{ng} / \mathrm{mL}$ will be found to have a biopsy positive for cancer. ${ }^{[6]}$ Moreover, the frequency of men with an elevated PSA and benign biopsy is country dependent ${ }^{[7]}$ and may be significantly different between rural and metropolitan populations in the same country. ${ }^{[8]}$

To complicate matters further, not all prostate cancers need treatment. It has been estimated that $23-42 \%$ of screen-detected prostate cancers are over treated. ${ }^{[2]}$ For every 100 men with an elevated PSA between $4 \mathrm{ng} / \mathrm{mL}$ and $10 \mathrm{ng} / \mathrm{mL}$, only about 14 will have a clinically significant prostate cancer detected. Eightysix will undergo a biopsy, with its associated risks, for what is found to be a benign disease. Infection and hemorrhage are the main potentially serious side effects of prostate biopsy, with a 30-day complication rate of $3.7 \%$, especially in older patients. ${ }^{[9]}$ Therefore, avoiding unnecessary biopsies is a worthwhile aim if it does not prejudice the number of clinically significant cancers detected.

Active surveillance is a recognized initial treatment option for men with early stage low-grade prostate cancer. The option to delay or avoid definitive therapy avoids or minimizes patient morbidity without compromising long-term outcomes in appropriately selected patients. ${ }^{[10,11]}$ According to the Prostate Cancer Intervention Versus Observation Trial, ${ }^{[12]}$ men with low risk disease (defined as a PSA $\leq 10 \mathrm{ng} / \mathrm{mL}$, a Gleason score $\leq 6$, and $\mathrm{T}$ stage 1 or $2 \mathrm{a}$ ) had no difference in all-cause mortality and prostate cancer-specific mortality, or in rate of progression to bony metastasis, when assigned to radical prostatectomy or to active observation. The criteria for active observation (AO) according to Epstein et al. ${ }^{[13]}$ are a diagnosis of prostate cancer, with three or fewer of the 12 prostate biopsy cores positive for cancer. That no single biopsy core with $>50 \%$ infiltration and a PSA density $<0.15 \mathrm{ng} / \mathrm{mL}$. Using these criteria to select patients with "insignificant disease" has a positive predictive value of $95 \%$ and a negative predictive value of $66 \% .^{[14]}$ These men are actively followed up with repeat annual biopsies. The timing of intervention after the initial diagnosis is based on variables such as PSA kinetics, Gleason grade progression, patient preference, and clinical or radiologic evidence of disease progression. ${ }^{[10,15]}$ An increase in the Gleason score at repeat biopsy is predictive of the time to active treatment and correlates with patient outcome. ${ }^{[16]}$ It has been reported that Gleason score progression occurs in approximately $20 \%$ of men, with more than $50 \%$ of cases occurring within two years of the initial diagnosis. ${ }^{[17]}$ However, a similar increase is seen in men subjected to immediate repeat biopsy when entering an AO program. ${ }^{[18]}$ This short time interval, when compared with the long natural history of prostate cancer, suggests that sampling error rather than tumor progression is probably the primary source of tumor upgrading in these men.

The use of other biomarkers, such as circulating prostate cells (CPCs), could be useful in re-categorizing the patients who could be more adequately treated by active surveillance. One such biomarker could be circulating tumor cells, or, in the case of prostate cancer, CPCs. We review the literature on circulating tumor cells both to try to answer the question of whether they could be clinically useful to detect prostate cancer and as a guide to initial treatment, observation, or active treatment. We review the process of cancer cell dissemination from the primary tumor and how this may affect cell markers, and thus determine the criteria for detecting or identifying circulating tumor cells. 
Methods of enrichment and detection of these cells are considered in how the method may affect what is being detected or not. Finally, we consider the clinical utility of these tests and how in day-to-day clinical practice they may help in decisions to proceed to prostate biopsy and treatment decisions of detected cancer.

A search for articles between the years 2000 and 2016, evaluating the detection of circulating tumor cells and CPCs was carried out using PubMed, Web of Science, and Cochrane Library. Case reports, review articles, non human models, and series involving fewer than 10 patients were excluded.

\section{THE DISSEMINATION OF CANCER CELLS FROM THE PRIMARY TUMOR}

The metastatic process by which tumor cells leave the primary tumor and implant, survive, and growth in distant sites is multistage and complex. Several steps are needed for the cancer cells to escape from the primary tumor and intra-vasation, towards extravagation and successful implantation in distant tissues. With the advent of prostate cancer screening and the use of total serum PSA, there has been a shift towards a diagnosis of localized cancers. ${ }^{[19]}$ However, despite being considered as localized by currently accepted staging methods, approximately $20-30 \%$ of patients suffer primary treatment failure, ${ }^{[20]}$ suggesting that cancer cells have disseminated prior to treatment. Using polymerase chain reaction amplification of PSA mRNA, it has been reported that prostate cancer cells disseminate early in the metastatic process into the circulation. ${ }^{[21]}$ These have been defined as primary circulating tumor cells, those detected before initial curative therapy.

Tumor cells may enter the circulation actively or passively; ${ }^{[22]}$ passive entry into the circulation is a result of vessel leakage by the growing tumor and external forces such as surgical manipulation at the time of biopsy; ${ }^{[23]}$ in these cases the circulating tumor cells do not require specific phenotypic characteristics. Active entry of tumor cells requires specific abilities which permit the cell to detach from the surrounding cells, survive free of them, and migrate towards blood vessels where they cross the capillary endothelium, enter the circulation, and disseminate. Thus, primary CPCs consist of a heterogeneous population ranging from metastatic initiating cells with specific cell properties $^{[24]}$ to non-aggressive cells without any specific survival ability.

In order to escape from the primary tumor, cancer cells exhibit a decreased expression in anchor proteins such as E-cadherin ${ }^{[25-27]}$ and beta-catenin ${ }^{[25,27]}$ and a loss of cytokeratins 8,18 , and 19 , which increases tumor cell plasticity. ${ }^{[28,29]}$ These changes occur in a coordinated fashion; they are higher in higher grade and less differentiated tumors. ${ }^{[28]}$ There is increased expression of matrix metalloproteinases; these zinccontaining endopeptidasesare activated in situ from their latent form and degrade the extracellular matrix. As such, they permit the cancers to disseminate to the circulation, implant, and form metastases. ${ }^{[29,30]}$ Increased expression of metalloproteinase-2 (MMP2) has been demonstrated ${ }^{[31-33]}$ and is associated with increasing Gleason score, pathological stage, and as a prognostic factor. ${ }^{[33,34]}$ Primary CPCs detected before prostate biopsy express MMP-2, whereas one hour post-biopsy there are a mixture of MMP-2 positive and negative CPCs, inferring that MMP-2 is important in CPC dissemination from the primary tumor. ${ }^{[35]}$

Epithelial to mesenchymal transition plays an important role in cancer dissemination. There is a change in the phenotypic expression of epithelial and mesenchymal markers, with increased expression of mesenchymal markers such as vimentin, $\mathrm{N}$-cadherin, or O-cadherin. ${ }^{[36,37]}$ These patterns of expression are heterogeneous with a global decrease in epithelial cell marker expression. ${ }^{[38]}$ However, CPCs that express only mesenchymal markers be may easily able to escape from the primary tumor, but for the same reason they have limited ability to implant in distant tissues. ${ }^{[39-42]}$ Intermediate states have been reported, with circulating tumor cells expressing both epithelial and mesenchymal markers. This increased state of cell plasticity may be advantageoust0 implantation at distant sites and the future formation of metastasis. This plasticity is the hallmark of cancer stem cells, ${ }^{[43-47]}$ and CPCs from prostate cancer patients have been reported to express $\mathrm{CD} 133^{[48]}$ or $\mathrm{ALDH} 1^{[49]}$ both markers of cell stem-ness.

One important epithelial marker that has relevance in the detection of CPCs is the epithelial cell adhesion molecule (EpCAM) (CD326). This is a $40 \mathrm{kD}$ glycoprotein that was originally identified as a marker for carcinoma, with an increased expression being identified in rapidly proliferating epithelial tumors.

EpCAM was initially thought to be important in cellular adhesion. However, more recent reports indicate that it plays a role in cell to cell signaling, in migration and proliferation of cancer cells, and possibly in the prevention of cell-cell adhesion. In normal cells there is a variable expression of EpCAM, but it is reported to be lower than that found in primary tumors. ${ }^{[50]}$

Thus, the specific phenotypic characteristics of 
cancer cells will determine their ability to disseminate into the circulation and may not reflect the general characteristics of the primary tumor due to the heterogeneous nature of individual cancer cells within the general tumor cell population.

In order to implant in distant sites CPCs must survive in the circulation. Only a few of the millions of tumor cells that are shed into the circulation are able to reach a distant site, implant, survive, evade the immune system, and eventually form a metastasis. It has been suggested that only $0.01 \%$ of circulating tumor cells can produce a single bony metastasis. ${ }^{\left[{ }^{[52}, 52\right]}$ CPCs obtained from men with castrate-resistant prostate cancer failed to produce metastasis when implanted in immune-compromised mice. ${ }^{[53]}$

Firstly, circulating tumor cells have to resist anchorage dependent cell death; over-expression of anti-apoptotic proteins such as $\mathrm{Bcl}-2$ overexpression ${ }^{[54]}$ or activation of specific pathways such as tropomyosin-related kinase $B(T r k B)^{[5]}$ have been reported. Secondly, they have to evade the host's immune systems. Circulating tumor cells from patients with colorectal cancer CD47 expression were increased. This marker is considered to be an anti-phagocytic signal expressed on cancer cells to prevent macrophages and dendritic cells from attacking them. The counterpart of this antiphagocytotic mechanism, the expression of prophagocytic calreticulin, was significantly decreased. ${ }^{[56]}$

Circulating tumor cells escape immune surveillance by shielding themselves from the immune cell population. It has been proposed that myeloid-derived suppressor cells facilitate the survival of cancer cells by creating a defensive shield. These myeloid-derived suppressors adhere to some of the circulating cancer cells, conferring a survival advantage.${ }^{[57]}$ Circulating tumors cells are rapidly coated by platelets. This may cause transfer of major histocompatibility complex (MHC) class I antigens on the tumor cell surface resulting in a high level of platelet-derived normal MHC class I. This coating of phenotypic normality disrupts the normal recognition of tumor cells by natural killer cells and T cell mediated immunity, thus permitting tumor cell survival. ${ }^{[58]}$

\section{METHODS TO DETECT AND CHARACTERIZE CIRCULATING TUMOR CELLS}

All methods of detecting circulating tumor cells are based first on enrichment of circulating tumor cells from venous blood and then on detection. The Food and Drug Administration (FDA) defines a validated biomarker assay as a system of analysis with established performance characteristics for which there is scientific evidence that elucidates the clinical significance of the results obtained. The stability, accuracy, and reproducibility of the assay are fundamental. Pre-analytical, analytical, and postanalytical variables all have to be controlled during the assay process. Parkinson et al.[59] have extensively reviewed this topic as have Panteleakou et al. ${ }^{[60]}$ Pre-analytical factors include the type of collection tube (including anticoagulant, storage, and transport conditions of the analytical variables), the type of enrichment and enumeration methods used, the sensitivity and specificity of the assay, the reproducibility of the assay between laboratories, and assay-specific controls. Other factors include the disease characteristics, how often the target cells are detectable in the study population or in other diseases or normal people, the positive and negative predictive values, and establishing cutoff values for a positive or negative test.

\section{Enrichment of circulating tumor cells from blood}

Methods for circulating tumor cell enrichment fall into three basic categories: density gradient centrifugation, cell filtration based on size or microfluidics, and immunemagnetic isolation, often anti-EpCAM antibodies; or a combination of methods.

Density gradient centrifugation is a simple, fast, and cheap process, separating cells based on their differing densities. Circulating tumor cells separate with the mononuclear blood cells (density $<1.077 \mathrm{~g} / \mathrm{mL}$ ), forming an opaque layer which can be removed and further analyzed. Red blood cells and granulocytes (density $>1.077 \mathrm{~g} / \mathrm{mL}$ ), being denser, settle towards the bottom of the tube. The method has poor sensitivity, as tumor cells may be lost when cells sediment to the granulocyte layer, or, if present as cell clusters, when they aggregate to the bottom of the tube. This may be important because circulating tumor cell clusters have been reported in patients with metastatic prostate cancer $^{[61]}$ and have been correlated with a worse outcome in breast cancer. ${ }^{[62]}$

Furthermore, if the centrifugation is performed immediately, whole blood may be mixed with the gradient solution, causing contamination. The OncoQuick ${ }^{\circledR}$ system uses a porous barrier to prevent such contamination. It has been reported that this system improves the depletion of mononuclear cells resulting in higher relative tumor cell enrichment as compared with standard gel separation. However, using cell-spiked blood samples there was a similar tumor cell recovery rate of between $70 \%$ and $90 \%$. ${ }^{[3,64]}$ 
Circulating tumor cells are larger than circulating blood cells; filtration methods are based on the physical properties of these cells and allow enrichment by size. Isolation of circulating tumor cells was first reported in $1964 .{ }^{[65]}$ The filters use pores measuring between 7.5-8.0 $\mu \mathrm{m}$ in diameter, thus capturing 85$100 \%$ of circulating tumor cells while retaining only $0.1 \%$ of circulating blood cells. ${ }^{[66]}$ Three commercially available filters are available: Screencell ${ }^{\circledR}$ Cyto, ISET ${ }^{\circledR}$, and Metacell ${ }^{\circledR}$. After filtration the filter membrane is removed and circulating tumor cells are identified by immunocytochemistry. Isolation of tumor cells by size is fast, simple, and reliable and does not require high-cost instrumentation. One drawback, though, is the need to process samples within four hours. The system does not detect the rare cells that are smaller than $8 \mu \mathrm{m}$; however, it will detect tumor cell clusters. The ISET ${ }^{\circledR}$ system detects one tumor cell in $1 \mathrm{~mL}$ of peripheral blood and permits the evaluation of tumor cells based on morphological criteria. False positivity occurs due to the lack of specificity of the enrichment technique. Normal epithelial or endothelial cells may be present due to coring by the sampling needle, and circulating cells have been described in samples taken from patients with benign conditions. ${ }^{[67,68]}$

Immunomagnetic selection methods use the specificity of antibody-antigen interactions combined with the physical properties of magnetic beads to separate tumor cells from blood cells due to the different expression of surface antigens in the differing cell populations. This is the basis of enrichment in the CellSearch $^{\circledast}$ system, the only FDA-approved method of detecting circulating tumor cells. In the CellSearch ${ }^{\circledR}$ system, iron particles are coated with the epithelial cell surface marker EpCAM, an epithelial marker that is overexpressed in some cancers but not in normal blood cells. ${ }^{[69]}$ However, EpCAM positive cells have been reported in patients with benign colon disease, ${ }^{[70]}$ and in the original report of Allard et al., ${ }^{[69]}$ women without evidence of breast cancer had "circulating tumor cells" detected in between 5 and $7 \%$ of cases, 1 cell/ $/ 7.5 \mathrm{~mL}$ blood sample. In addition, the epithelial phenotype of circulating tumor cells changes, as a result of the epithelial to mesenchyme transition the expression of EpCAM decreases and thus there may be failure of enrichment and as a result circulating tumor cells are not detected. This applies also to microchip devices that incorporate microposts labeled with anti-EpCAM (CTC Chip), using EpCAM coated beads (Dynabeads ${ }^{\circledR}$ Epithelial enriched)(MACS/auto MACS $\left.^{\circledR}\right)\left(\right.$ AdnaTest $^{\circledR}$ ) or using microvortices in a herringbone pattern to increase the number of interactions between the EpCAM-coated chip surface and circulating tumor cells. ${ }^{[71]}$ The same can be said for cytokeratin-based enrichment methods. ${ }^{[72]}$

Negative enrichment methods that deplete normal blood cells using the pan-leukocyte antigen CD45 after red cell lysis have also been used. ${ }^{[73]}$

\section{Detection of circulating tumor cells}

For the detection of enriched circulating tumor cells, two methods have been used: immunocytochemistry and reverse transcriptase-polymerase chain reaction (RT-PCR).

\section{Immunocytochemistry}

The advantage of methods using immunocytochemistry is the morphological analysis of the detected cells. The International Society of Hematotherapy and Graft Engineering criteria ${ }^{[74]}$ for circulating tumor cell identification are an object with the appearance of cell with a nucleus. Most methods use a combination of markers; the CellSearch ${ }^{\circledR}$ system defines a circulating tumor cell as one positive for cytokeratin, negative for the pan-leukocyte antigen CD45, and expressing DAPI $\left(4^{\prime}\right.$, 6-diamidino-2-phenylindole) nuclear staining. The ISET ${ }^{\circledR}$ and Metace $\|^{\circledR}$ systems use anticytokeratin staining, while the CTC membrane microfilter, Rosettesep ${ }^{\circledR}$ and Nanovelcro CTC Chip ${ }^{\circledR}$, use immunofluorescence with a cocktail of anti-EpCAM, anti-cytokeratin, and CD45. All these methods in essence detect circulating epithelial cells and are not tissue specific. Using basic cell density methods, some authors have attempted to use more specific markers to detect circulating tumor cells, anti-PSA for prostate cancer, ${ }^{[75]}$ anti-mammoglobin for breast cancer. ${ }^{[76]}$ As such, these methods are not able to differentiate between benign and malignant circulating "epithelial" cells. In patients with benign colonic diseases, up to $29 \%$ of patients were positive for the Epispot ${ }^{\circledR}$ assay, and up to $19 \%$ of patients were positive for the CellSearch ${ }^{\circledR}$ assay. ${ }^{[70]}$ One group has used the combination antiPSA and anti-P504S to address this problem. The expression of P504S has been used to differentiate between benign and malignant prostate tissues in biopsy samples. P504S is expressed in prostate cancer cells and those of prostate intra-epithelial neoplasia, but not in benign prostatic tissue. ${ }^{[77,78]}$ The authors report that PSA positive cells can be detected in men with benign prostatic disease, especially prostatitis, but these cells are P504S negative, whereas men with prostate cancer had PSA positive cells which also expressed P504S. ${ }^{[79]}$

In reference to circulating cell clusters, the identification of CTC clusters (defined as $\geq 2$ CTCs) has been related o poor outcome in stage III-IV breast cancer using the CellSearch system, ${ }^{[80]}$ whereas Paoletti et al.$^{\left[{ }^{[1]}\right.}$ defined CTC clusters as $\geq 3$ CTCs in the CellSearch gallery 
and their presence was associated with a worse prognosis. However, there is no consensus regarding the morphologic characteristics necessary to define cell clusters using the CellSearch system.

\section{RT-PCR detection of circulating tumor cells}

RT-PCR is a more sensitive method than immunocytochemistry to detect circulating tumor cells. However, it has its limitations in that; (1) there may be amplification of nonspecific gene products; (2) it lacks thoroughly validated protocols for sample processing, RNA-preparation, cDNA synthesis, and PCR conditions; (3) it lacks rigorous quality control measures on a per-sample basis (the lack of a validated method increases the possibility of variations in sensitivity, specificity, and the potential of nonspecific amplification products being detected); and (4) there is no morphological confirmation of tumor cells.

The number of articles describing single or multiple markers to characterize CTCs using RT-qPCR in the blood of cancer patients has increased greatly in recent years, especially in breast cancer. ${ }^{[81-85]}$ The Adnatest ${ }^{\circledR}$ PC CTC platform consists of the ProstateCancerSelect ${ }^{\circledR}$ and ProstateCancerDetect ${ }^{\circledR}$ system. The ProstateCancerSelect ${ }^{\circledR}$ system allows for an enrichment of tumor cells by an antibodymix (anti-EpCAM, anti-Her2) linked to magnetic particles and mRNA isolated from the selected cells. The ProstateCancerDetect ${ }^{\circledR}$ System transcribes the isolated mRNA into cDNA, and a multiplex PCR is performed for the analysis of tumor-associated gene expression (PSA, PSMA, EGFR). The use of multiplex systems permits an increased characterization of circulating tumor cells.

Cell clusters cannot be detected using methods of RT-PCR. Enumeration systems are normally imaged based, using immunocytochemistry or laser scanning techniques. Table 1 shows a summary of each commercial CTC detection kit.

\section{CLINICAL USE OF THE DETECTION OF PRIMARY CPCS}

\section{In the detection of prostate cancer}

There are few reported studies of the use of circulating tumor cells to detect prostate cancer. Early studies using different detection methods compared the presence of these cells in healthy controls, men with localized cancer, and men with metastatic prostate cancer. Circulating tumor cells appear to be less frequently detected in men with localized prostate cancer than those patients with advanced or metastatic cancer. In men with an increased PSA, there was a detection rate of $20 \%$ in men with cancer and in $21 \%$ of men with a benign prostatic disease. ${ }^{[86]}$ Using the same CellSearch $^{\circledR}$ system Thalgott et al. ${ }^{[87]}$ failed to detect a difference between men with localized prostate cancer and healthy controls. Using RT-PCR, only $8 \%$ of men with localized prostate cancer were positive for circulating tumor cells, and the results were concordant with the use of the CellSearch ${ }^{\circledR}$ system. ${ }^{[88]}$ In men with high risk non-metastatic prostate cancer and prior to any therapy, $14 \%$ of men had circulating tumor cells detected. ${ }^{[89]}$

In contrast, using the MetaCel${ }^{\circledR}$ system, circulating tumor cells were identified in $52 \%$ of men with localized prostate cancer, ${ }^{[90]}$ while Stott et al. ${ }^{[91]}$ using a CTC chip platform detected circulating tumor cells with a cut-off value of $\geq 14$ to determine a positive test found $42 \%$ of men with localized prostate cancer to be positive. However, using a telomerase-based method Fizazi et al. ${ }^{[92]}$ detected tumor cells in $79 \%$ of men with localized prostate cancer. Using a combination of PSA and P504S immunocytochemistry, a study of over 1,000 men undergoing prostate biopsy for an elevated PSA reported that $35 \%$ of men were CPC positive; used as a sequential test after PSA screening, it showed a sensitivity of $81 \%$, specificity of $89 \%$, and a negative predictive value of $90 \% .^{[93]}$ The same group compared this method of CPC detection with PSA kinetics, age-defined PSA cut-off values, and the Montreal nomogram, and reported that CPC detection was superior in predicting prostate cancer at first biopsy. ${ }^{[94-96]}$ They also concluded that men with lowgrade small volume tumors, those complying with the criteria for active observation, were CPC negative..$^{[97]}$ Men with benign prostatic disease, especially

Table 1: Enrichment and detection systems of commercially available kits

\begin{tabular}{lll}
\hline System & Enrichment & Detection \\
\hline CellSearch & IC EpCAM & IF CK, CD45, DAPI \\
Epispot & IC non-EpCAM & Secretion of proteins \\
& & CK19, MUC1, PSA \\
Metacell & Cell size & ICC for CK \\
CTC membrane & Cell size & IF for CK \\
RosetteSep & ID CD45 & IF for CK EpCAM CD45 \\
Nanovelcro chip & Microfluids and IC & IF for CK EpCAM CD45 \\
Adnatest & IC EpCAM & qRT-PCR \\
Ficoll-Paque & Cell density & ICC PSA and P504S \\
\hline
\end{tabular}

IC: immune-capture; IF: immunofluorescence; CK: cytokeratin; ICC: immunocytochemistry; ID: immune-depletion; PSA: prostatespecific antigen

Table 2: Methods reported in the detection and pretreatment prognosis of prostate cancer

\begin{tabular}{lll}
\hline & Diagnosis & Prognosis \\
\hline CellSearch & Not useful & Not useful \\
Rt-PCR & Not useful & Possibly useful \\
Ficol-Paque & Possibly useful & Possibly useful \\
\hline
\end{tabular}

Rt-PCR: reverse transcriptase-polymerase chain reaction 
prostatitis, may have PSA-positive circulating tumor cells detected but they were P504S negative. ${ }^{[79]}$ Validation in multicenter prospective clinical trials is therefore essential to assess its potential usefulness [Table 2].

\section{As a prognostic marker to guide in the decision to treat or to observe}

As a prognostic factor, primary CPCs do not appear to have a definitive use. This is because the majority of these cells will be eliminated by the primary treatment, be destroyed by the host's defense mechanisms, or not have the phenotypic characteristics to be able to implant and survive. In men with early stage prostate cancer, the detection of circulating tumor cells using RT-PCR was associated with a worse prognosis. ${ }^{[98]}$ Using PSA and PSMA genes to identify circulating tumor cells in men prior to radical prostatectomy, men negative for the test had significantly better outcomes. ${ }^{[99]}$ Using a positive/negative cutoff value, men negative for circulating tumor cells have a significantly better 10-year biochemical free failure survival after radical prostatectomy than men positive for CPCs. ${ }^{[100]}$

When used as a predictive prognostic factor and compared with predictive nomograms, using the CellSearch ${ }^{\circledR}$ system $^{[101]}$ or the PSA/P504S combined immunocytochemical assay, ${ }^{[102]}$ there was little if any improvement in predicting the prognosis of men pretreatment [Table 2].

Thus, the possibility of identifying circulating tumor cells in early stage prostate cancer seems to be achievable. However, the methods need to be clinically validated in multicenter studies. The use of primary CPCs as a sequential test to detect prostate cancer and as a guide to treatment seems a very fascinating area of research that warrants further studies.

\section{Acknowledgments}

The author wants to thank Mrs. Ana Maria Palazuelos for her help in writing this manuscript.

\section{Financial support and sponsorship} Nil.

\section{Conflicts of interest}

Dr. Murray has received consultancy fees from Viatar CTC solutions, Boston, USA.

\section{Patient consent}

There is no patient involved.

\section{Ethics approval}

This article does not contain any studies with human participants or animals.

\section{REFERENCES}

1. Jemal A, Siegel R, Ward E, Murray T, Xu J, Smigal C, Thun MJ Cancer statistics. CA Cancer J Clin 2006;56:106-30.

2. Draisma G, Etzioni R, Tsodikov A, Mariotto A, Wever E, Gulati R, Feuer E, de Koning H. Lead time and over-diagnosis in prostatespecific antigen screening: importance of methods and context. $J$ Natl Cancer Inst 2009;101:374-83.

3. Andiole GL, Crawford ED, Grubb RL 3rd, Buys SS, Chia D, Church TR, Fouad MN, Gelmann EP, Kvale PA, Reding DJ, Weissfeld JL, Yokochi LA, O'Brien B, Clapp JD, Rathmell JM, Riley TL, Hayes RB, Kramer BS, Izmirlian G, Miller AB, Pinsky PF, Prorok PC, Gohagan JK, Berg CD; PLCO Project Team. Mortality results from a randomized prostate cancer screening trial. $N$ Eng $J$ Med 2009;360:1310-9.

4. Schroder FH, Hugosson J, Roobol MJ, Tammela TL, Ciatto S, Nelen V, Kwiatkowski M, Lujan M, Lilja H, Zappa M, Denis LJ, Recker F, Berenguer A, Määttänen L, Bangma CH, Aus G, Villers A, Rebillard X, van der Kwast T, Blijenberg BG, Moss SM, de Koning HJ, Auvinen $\mathrm{A}$; ERSPC Investigators. Screening and prostate cancer mortality in a randomized European study. N Eng J Med 2009;360:1320-8.

5. Carter HB, Albertsen PC, Barry MJ, Etzioni R, Freedland SJ, Greene KL, Holmberg L, Kantoff P, Konety BR, Murad MH, Penson DF, Zietman AL. Early detection of prostate cancer: AUA guideline. $J$ Urol 2013;190:419-26.

6. Smith DS, Humphrey PA, Catalona WJ. The early detection of prostate carcinoma with prostate specific antigen: the Washington University experience. Cancer 1997;80:1852-6.

7. Belbase NP, Agrawal CS, Pokharel PK, Agrawal S, Lamsal M, Shakya VC. Prostate cancer screening in a healthy population cohort in Eastern Nepal: an explanatory trial study. Asian Pac J Cancer Prev 2013;14:2835-8

8. Lalitha K, Suman G, Pruthvish S, Mathew A, Murthy NS. Estimation of time trends of incidence of prostate cancer: an Indian scenario. Asian Pac J Cancer Prev 2012;13:6245-50.

9. Anastasiadis E, van der Meulin J, Emberton M. Hospital admissions after TRUS biopsy of the prostate in men diagnosed with prostate cancer: a database analysis in England. Int J Urol 2015;22:181-6.

10. Dall'Era MA, Cooperberg MR, Chan JM, Davies BJ, Albertsen PC, Klotz LH, Warlick CA, Holmberg L, Bailey DE Jr, Wallace ME, Kantoff PW, Carroll PR. Active surveillance for early stage prostate cancer: review of the current literature. Cancer 2008;112:1650-9.

11. Warlick C, Trock BJ, Landis P, Epstein JI, Carter HB. Delayed versus immediate surgical intervention and prostate cancer outcome. $J$ Natl Cancer Inst 2006;98:355-7.

12. Wilt TJ, Brawer MK, Jones KM, Barry MJ, Aronson WJ, Fox S, Gingrich JR, Wei JT, Gilhooly P, Grob BM, Nsouli I, Iyer P, Cartagena R, Snider G, Roehrborn C, Sharifi R, Blank W, Pandya P, Andriole GL, Culkin D, Wheeler T; Prostate Cancer Intervention versus Observation Trial (PIVOT) Study Group. Radical prostatectomy versus observation for localized prostate cancer. $N$ Eng $J$ Med 2012;367:203-13

13. Epstein JI, Walsh PC, Carmichael M, Brendler CB. Pathologic and clinical findings to predict tumor extent of non-palpable (stage T1c) prostate cancer. JAMA 1994;271:368-74.

14. Patel MI, DeConcini DT, Lopez-Corona E, Ohori M, Wheeler T, Scardino PT. An analysis of men with clinically localized prostate cancer who deferred definitive treatment. J Urol 2004;171:1520-4.

15. Klotz L. Active surveillance versus radical treatment for favorable risk localized prostate. Curr Treat Options Oncol 2006;7:355-62.

16. Carter HB, Walsh PC, Landis P, Epstein JI. Expectant management of non-palpable prostate cancer with curative intent: preliminary results. J Urol 2002;167:1231-4. 
17. Sheridan TB, Carter HB, Wang W, Landis PB, Epstein JI. Change in prostate cancer grade over time in men followed expectantly for stage T1c disease. J Urol 2008;179:901-4.

18. Berglund RK, Materson TA, Vora KC, Eggener SE, Eastham JA, Guillonneau BD. Pathological upgrading and up staging with immediate repeat biopsy in patients eligible for active surveillance. $J$ Urol 2008;180:1964-7.

19. Pound CR, Partin AW, Eisenberger MA, Chan DW, Pearson JD, Walsh PC. The natural history of progression after PSA elevation following radical prostatectomy. JAMA 1999;281:1591-7.

20. Amling CL, Blute ML, Bergstrahl EJ, Seay TM, Slezak J, Zincke H. Long term hazard of progression after radical prostatectomy for clinically localized prostate cancer: continued risk of biochemical failure after 5 years. J Urol 2000;164:101-5.

21. Moreno JG, Croce CM, Fischer R, Monne M, Vihko P, Mulholland $\mathrm{SG}$, Gomella LG. Detection of hematogenous micrometastasis in patients with prostate cancer. Cancer 1992;52:6110-2.

22. Joosse SA, Gorges TM, Pantel K. Biology, detection, and clinical implications of circulating tumor cells. EMBO Mol Med 2015;7:1-11.

23. Murray NP, Reyes E, Orellana N, Fuentealba C, Dueñas R, Jacob O. Expression of P504S and matrix metalloproteinase-2 in circulating prostate cells disseminated as a result of transrectal ultrasound guided biopsy as determined by immunocytochemistry: clinical implications. ArchEsp Urol 2015;68:474-81.

24. Chaffer CL, Weinberg RA. A perspective on cancer cell metastasis. Science 2011;331:1559-64.

25. Jaggi M, Johansson SL, Baker JJ, Smith LM, Galich A, Balaji KC. Aberrant expression of E-cadherin and beta-catenin in human prostate cancer. Urol Onc 2005;23:402-6.

26. Umbas R, Schalken JA, AaldersTW, Carter BS, Karthaus HF, Schaafsma HE, Debruyne FM, Isaacs WB. Expression of the cellular adhesion molecule E-cadherin is reduced or absent in high-grade prostate cancer. Cancer Res 1992;52:5104-9.

27. Pontes J Jr, Srougi M, Borra PM, Dall' Oglio MF, Ribeiro-Filho LA, Leite KR. E-cadherin and beta-catenin loss of expression related to bone metastasis in prostate cancer. Appl Immunohistochem Mol Morphol 2010;18:179-84.

28. Murant SJ, Handley J, Stower M, Reid N, Cussenot O, Maitland NJ. Co-ordinated changes in expression of cell adhesion molecules in prostate cancer. Eur J Cancer 1997;33:263-71.

29. Alberti I, Barboro P, Barbesino M, Sanna P, Pisciotta L, Parodi S, Nicolò G, Boccardo F, Galli S, Patrone E, Balbi C. Changes in the expression of cytokeratins and nuclear matrix proteins are correlated with the level of differentiation in human prostate cancer. $J$ Cell Biochem 2000;79:471-85.

30. Chambers AF, Matrisian LM. Changing views of the role of matrix metalloproteinases in metastasis. J Natl Cancer Inst 1997;89:1260-70.

31. Stearns ME, Stearns M. Immunohistochemical studies of activated matrix metalioproteinase-2 (MMP-2a) expression in human prostate cancer. Oncol Res 1996;8:63-7.

32. Wood DP, Banerjee M. Presence of circulating prostate cells in the bone marrow of patients undergoing radical prostatectomy is predictive of disease-free survival. J Clin Oncol 1997;15:3451-7.

33. Kuniyasu H, Troncoso P, Johnston D, Bucana CD, Tahara E, Fidler IJ, Pettaway CA. Relative expression of type IV collagenase, E-cadherin, and vascular endothelial growth factor/vascular permeability factor in prostatectomy specimens distinguishes organ-confined from pathologically advanced prostate cancers. Clin Cancer Res 2000;6:2295-308.

34. Ross JS, Kaur P, Sheehan CE, Fisher HA, Kaufman RA Jr, Kallakury BV. rognostic significance of matrix metalloproteinase 2 and tissue inhibitor of metalloproteinase 2 expression in prostate cancer. Mod Pathol 2003;16:198-205.
35. Trudel D, Fradet Y, Meyer F, Harel F, Têtu B. Significance of MMP-2 expression in prostate cancer: an immunohistochemical study. Cancer Res 2003;63:8511-5.

36. Murray NP, Reyes E, Orellana N, Fuentealba C, Dueñas R, Jacob O. Expression of P504S and matrix metalloproteinase-2 in circulating prostate cells disseminated as a result of transrectal ultrasound guided biopsy as determined by immunocytochemistry: clinical implications. Arch Esp Urol 2015;68:474-81.

37. Friedlander TW, Ngo VT, Dong H, Premasekharan G, Weinberg V, Doty S, Zhao Q, Gilbert EG, Ryan CJ, Chen WT, Paris PL. Detection and characterization of invasive circulating tumor cells derived from men with metastatic castration-resistant prostate cancer. Int J Cancer 2014;134:2284-93.

38. Armstrong AJ, Marengo MS, Oltean S, Kemeny G, Bitting RL, Turnbull JD, Herold CI, Marcom PK, George DJ, Garcia-Blanco MA. Circulating tumor cells from patients with advanced prostate and breast cancer display both epithelial and mesenchymal markers. Mol Cancer Res 2011;9:997-1007.

39. Chen CL, Mahalingam D, Osmulski P, Jadhav RR, Wang CM, Leach RJ, Chang TC, Weitman SD, Kumar AP, Sun L, Gaczynska ME, Thompson IM, Huang TH. Single-cell analysis of circulating tumor cells identifies cumulative expression patterns of EMT-related genes in metastatic prostate cancer. Prostate 2013;73:813-26.

40. Ocana OH, Corcoles R, Fabra A, Moreno-Bueno G, Acloque H, Vega S, Barrallo-Gimeno A, Cano A, Nieto MA. Metastatic colonization requires the repression of the epithelial-mesenchymal transition inducer Prrx1. Cancer Cell 2012;22:709-24.

41. Tsai JH, Donaher JL, Murphy DA, Chau S, Yang J. Spatiotemporal regulation of epithelial-mesenchymal transition is essential for squamous cell carcinoma metastasis. Cancer Cell 2012;22:725-36.

42. Tsuji T, Ibaragi S, Shima K, Hu MG, Katsurano M, Sasaki A, Hu GF. Epithelial-mesenchymal transition induced by growth suppressor p12CDK2-AP1 promotes tumor cell local invasion but suppresses distant colony growth. Cancer Res 2008;68:10377-86.

43. Celia-Terrassa T, Meca-Cortes O, Mateo F. Martínez de Paz A, Rubio N, Arnal-Estapé A, Ell BJ, Bermudo R, Díaz A, Guerra-Rebollo M, Lozano JJ, Estarás C, Ulloa C, Álvarez-Simón D, Milà J, Vilella R, Paciucci R, Martínez-Balbás M, de Herreros AG, Gomis RR, Kang Y, Blanco J, Fernández PL, Thomson TM. Epithelial-mesenchymal transition can suppress major attributes of human epithelial tumorinitiating cells. J Clin Invest 2012;122:1849-68.

44. Fidler IJ, Kripke ML. Metastasis results from preexisting variant cells within a malignant tumor. Science 1977;197:893-5.

45. Baccelli I, Schneeweiss A, Riethdorf S, Stenzinger A, Schillert A, Vogel V, Klein C, Saini M, Bäuerle T, Wallwiener M, Holland-Letz T, Höfner T, Sprick M, Scharpff M, Marmé F, Sinn HP, Pantel K, Weichert W, Trumpp A. Identification of a population of blood circulating tumor cells from breast cancer patients that initiates metastasis in a xenograft assay. Nat Biotechnol 2013;31:539-44.

46. Bednarz-Knoll N, Alix-Panabières C, Pantel K. Plasticity of disseminating cancer cells in patients with epithelial malignancies. Cancer Metastasis Rev 2012;31:673-87.

47. Tam WL, Weinberg RA. The epigenetics of epithelial-mesenchymal plasticity in cancer. Nat Med 2013;19:1438-49.

48. Todenhöfer T, Hennenlotter J, Feyerabend S, Aufderklamm S, Mischinger J, Kühs U, Gerber V, Fetisch J, Schilling D, Hauch S, Stenzl A, Schwentner C. Preliminary experience on the use of the Adnatest(R) system for detection of circulating tumor cells in prostate cancer patients. Anticancer Res 2012;32:3507-13.

49. Alix-Panabières $\mathrm{C}$, Pantel $\mathrm{K}$. Challenges in circulating tumor cell research. Nat Rev Cancer 2014;14:623-31.

50. Trzpis M, McLaughhlin PMJ, de Leij LMFH, Harmsen MC. Epithelial cell adhesion molecule: more than a carcinoma marker and adhesion 
molecule. Am J Pathol 2007;171:386-95.

51. Fidler IJ. Metastasis: quantitative analysis of distribution and fate of tumor emboli labeled with 125 I-5-iodo-2'-deoxyuridine. J Natl Cancer Inst 1970;45:773-82.

52. Liotta LA, Saidel MG, Kleinerman J. The significance of hematogenous tumor cell clumps in the metastatic process. Cancer Res 1976;36:889-94.

53. Carvalho FL, Simons BW, Antonarakis ES, Rasheed Z, Douglas N, Villegas D, Matsui W, Berman DM. Tumorigenic potential of circulating prostate tumor cells. Oncotarget 2013;4:413-21.

54. Smerage JB, Budd GT, Doyle GV, Brown M, Paoletti C, Muniz M, Miller MC, Repollet MI, Chianese DA, Connelly MC, Terstappen LW, Hayes DF. Monitoring apoptosis and Bcl-2 on circulating tumor cells in patients with metastatic breast cancer. Mol Oncol 2013;7:680-92.

55. Douma S, Van Laar T, Zevenhoven J, Meuwissen R, Van Garderen E, Peeper DS. Suppression of anoikis and induction of metastasis by the neurotrophic receptor TrkB. Nature 2004;430:1034-9.

56. Steinert G, Schölch S, Niemietz T, Iwata N, García SA, Behrens B, Voigt A, Kloor M, Benner A, Bork U, Rahbari NN, Büchler MW, Stoecklein NH, Weitz J, Koch M. Immune escape and survival mechanisms in circulating tumor cells of colorectal cancer. Cancer Res 2014;74:1694-704.

57. Liu Q, Liao Q, Zhao Y. Myeloid derived suppressor cells (MDSC) facilitate distant metastasis of malignancies by shielding circulating tumor cells (CTCs) from immune surveillance. Med Hypothesis 2016;87:34-9.

58. Placke T, Örgel M, Schaller M, Jung G, Rammensee HG, Kopp HG, Salih HR. Platelet derived MHC class I confers a pseudo-normal phenotype to cancer cells that subverts the antitumor reactivity of natural killer immune cells. Cancer Res 2012;72:440-8.

59. Parkinson DR, Dracopoli N, Petty BG, Compton C, Cristofanilli M, Deisseroth A, Hayes DF, Kapke G, Kumar P, Lee JSh, Liu MC, McCormack R, Mikulski S, Nagahara L, Pantel K, Pearson-White S, Punnoose EA, Roadcap LT, Schade AE, Scher HI, Sigman CC, Kelloff GJ. Considerations in the development of circulating tumor cell technology for clinical use. J Translat Med 2012;10:138.

60. Panteleakou Z, Lembessis P. Sourla A, Pissimissis N, Polyzos A, Deliveliotis C, Koutsilieris M. Detection of circulating tumor cells in prostate cancer patients: methodological pitfalls and clinical relevance. Mol Med 2009;15:101-14.

61. Brandt B, Junker R, Griwatz C, Heidl S, Brinkmann O, Semjonow A, Assmann G, Zänker KS. Isolation of prostate-derived single cells and cell clusters from human peripheral blood. Cancer Res 1996;56:4556-61.

62. Mu Z, Wang C, Ye Z, Austin L, Civan J, Hyslop T, Palazzo JP, Jaslow R, Li B, Myers RE, Jiang J, Xing J, Yang H, Cristofanilli M. Prospective assessment of the prognostic value of circulating tumor cells and their clusters in patients with advanced-stage breast cancer. Breast Cancer Res Treat 2015;154:563-71.

63. Gertler R, Rosenberg R, Fuehrer K, Dahm M, Nekarda H, Siewert JR. Detection of circulating tumor cells in blood using an optimized density gradient centrifugation. Recent Results Cancer Res 2003;162:149-55.

64. Rosenberg R, Gertler R, Friederichs J, Fuehrer K, Dahm M, Phelps R, Thorban S, Nekarda H, Siewert JR. Comparison of two density gradient centrifugation systems for the enrichment of disseminated tumor cells in blood. Cytometry 2002;49:150-8.

65. Seal SH. A sieve for the isolation of cancer cells and other large cells from blood. Cancer 1964;17:637-42.

66. Plaks V, Koopman CD, Werb Z. Cancer. Circulating tumor cells. Science 2013;341:1186-8.

67. De Giorgi V, Pinzani P, Salvianti F, Grazzini M, Orlando C, Lotti T, Pazzagli M, Massi D. Circulating benign nevus cells detected by ISET technique: warning for melanoma molecular diagnosis. Arch Dermatol 2010;146:1120-4.
68. Rhim AD, Thege FI, Santana SM, Lannin TB, Saha TN, Tsai S, Maggs LR, Kochman ML, Ginsberg GG, Lieb JG, Chandrasekhara V, Drebin JA, Ahmad N, Yang YX, Kirby BJ, Stanger BZ. Detection of circulating pancreas epithelial cells in patients with pancreatic cystic lesions. Gastroenterology 2014;146:647-51.

69. Allard WJ, Matera J, Miller MC, Repollet M, Connelly MC, Rao C, Tibbe AG, Uhr JW, Terstappen LW. Tumor cells circulate in the peripheral blood of all major carcinomas but not in healthy subjects or patients with nonmalignant diseases. Clin Cancer Res 2004;10:6897-904.

70. Pantel K, Denéve E, Nocca D, Coffy A, Vendrell JP, Maudelonde T, Riethdorf S, Alix-Panabières C. Circulating epitelial cells in patients with benign colon diseases. Clin Chem 2012;58:936-40.

71. Stott SL, Hsu CH, Tsukrov DI, Yu M, Miyamoto DT, Waltman BA, Rothenberg SM, Shah AM, Smas ME, Korir GK, Floyd FP Jr, Gilman AJ, Lord JB, Winokur D, Springer S, Irimia D, Nagrath S, Sequist LV, Lee RJ, Isselbacher KJ, Maheswaran S, Haber DA, Toner M. Isolation of circulating tumor cells using a microvortex generating herring bone-chip. Proc Natl Acad Sci U S A 2010;107:18392-7.

72. Chinen LT, de Carvalho FM, Rocha BM, Aguiar CM, Abdallah EA, Campanha D, Mingues NB, de Oliveira TB, Maciel MS, Cervantes GM, Dettino AL, Soares FA, Paterlini-Bréchot P, Fanelli MF. Cytokeratin based CTC counting unrelated to clinical follow up. $J$ Thorac Dis 2013;5:593-9.

73. Liu Z, Fusi A, Klopocki E, Schmittel A, Tinhofer I, Nonnenmacher A, Keilholz U. Negative enrichment by immunomagnetic-nanobeads for unbiased characterization of circulating tumor cells from peripheral blood of cancer patients. J Transl Med 2011;9:70.

74. Borgen E, Naume B, Nesland JM, Kvalheim G, Beiske K, Fodstad O, Diel I, Solomayer EF, Theocharous P, Coombes RC, Smith BM, Wunder E, Marolleau JP, Garcia J, Pantel K. Standardization of the immunocytochemical detection of cancer cells in BM and blood. I. Establishment of objective criteria for the evaluation of immunostained cells. Cytotherapy 1999;1:377-88.

75. Murray NP, Calaf GM, Badinez L, Dueñas R, Badinez O, Orellana N, Reyes E, Fuentealba C. P504S expressing circulating prostate cells as a marker for prostate cancer. Oncol Reports 2010;24:687-92.

76. Murray NP, Miranda R, Ruiz A, Droguett E. Diagnostic yield of primary circulating tumor cells in women suspected of breast cancer: the BEST (Breast Early Screening Test) study. Asian Pac J Cancer Prev 2015;16:1929-34.

77. Zhou M, ChinnaiyanAM, Kleer CG, Lucas PC, Rubin MA. Alphamethylacyl-CoA racemase: a novel tumor marker over-expressed in several human cancers and their precursor lesions. Am J of Surg Pathol 2002;26:926-31.

78. Beach R, Gown AM, De Peralta-Venturina MN, Folpe AL, Yaziji H, Salles PG, Grignon DJ, Fanger GR, Amin MB. P504S immunohistochemical detection in 405 prostatic specimens including 376 18-gauge needle biopsies. Am J Surg Pathol 2002;26:1588-96.

79. Murray NP, Reyes E, Badinez L, Orellana N, Fuentealba C, Olivares R, Porcell J, Dueñas R. Circulating prostate cells found in men with benign prostate disease are p504s negative: clinical implications. $J$ Oncol 2013;2013:165014.

80. Mu Z, Wang C, Ye Z, Austin L, Civan J, Hyslop T, Palazzo JP, Jaslow R, Li B, Myers RE, Jiang J, Xing J, Yang H, Cristofanilli M. Prospective assessment of the prognostic value of circulating tumor cells and their clusters in patients with advanced-stage breast cancer. Breast Cancer Res Treat 2015;154:563-71.

81. Paoletti C, Li Y, Muniz MC, Kidwell KM, Aung K, Thomas DG, Brown ME, Abramson VG, Irvin WJ Jr, Lin NU, Liu MC, Nanda R, Nangia JR, Storniolo AM, Traina TA, Vaklavas C, Van Poznak CH, Wolff AC, Forero-Torres A, Hayes DF; Translational Breast Cancer Research Consortium (TBCRC). Significance of circulating tumor cells in metastatic triple-negative breast cancer patients within a randomized, 
phase ii trial: TBCRC 019. Clin Cancer Res 2015;21:2771-9.

82. Molloy TJ, Devriese LA, Helgason HH, Bosma AJ, Hauptmann M, Voest EE, Schellens JH, van't Veer LJ. A multimarker qPCR-based platform for the detection of circulating tumor cells in patients with early-stage breast cancer. Br J Cancer 2011;104:1913-9.

83. Ignatiadis M, Kallergi G, Ntoulia M, Perraki M, Apostolaki S, Kafousi M, Chlouverakis G, Stathopoulos E, Lianidou E, Georgoulias V, Mavroudis D. Prognostic value of the molecular detection of circulating tumor cells using a multi-marker reverse transcriptionPCR assay for cytokeratin 19, mammaglobin A, and HER2 in early breast cancer. Clin Cancer Res 2008;14:2593-600.

84. Strati A, Markou A, Parisi C, Politaki E, Mavroudis D, Georgoulias V, Lianidou E. (2011) Gene expression profile of circulating tumor cells in breast cancer by RT-PCR. BMC Cancer 2011;11:422.

85. Obermayr E, Sanchez-Cabo F, Tea MK, Singer CF, Krainer M, Fischer MB, Sehouli J, Reinthaller A, Horvat R, Heinze G, Tong D, Zeillinger R. Assessment of a six-gene panel for the molecular detection of circulating tumor cells in the blood of female cancer patients. $B M C$ Cancer 2010;10:666.

86. Davis JW, Nakanishi H, Kumar VS, Bhadkamkar VA, McCormack R, Fritsche HA, Handy B, Gornet T, Babaian RJ. Circulating tumor cells in peripheral blood samples from patients with increased serum prostate specific antigen: initial results in early prostate cancer. J Urol 2008;179:2187-91.

87. Thalgott M, Rack B, Mauerer T, Souvatzoglou M, Eiber M, Kreß V, Heck MM, Andergassen U, Nawroth R, Gschwend JE, Retz M. Detection of circulating tumor cells in different stages of prostate cancer. J Cancer Res Clin Oncol 2013;139:755-63.

88. Helo P, Cronin AM, Danila DC, Wenske S, Gonzalez-Espinoza R, Anand A, Koscuiszka M, Väänänen RM, Pettersson K, Chun FK, Steuber T, Huland H, Guillonneau BD, Eastham JA, Scardino PT, Fleisher M, Scher HI, Lilja H. Circulating prostate tumor cells detected by RT-PCR in men with localized or castration refractory prostate cancer: concordance with CellSearch assay and association with bone metastasis and survival. Clin Chem 2009;55:765-73.

89. Loh J, Jovanovic L, Lehman M, Capp A, Pryor D, Harris M, Nelson C, Martin J. Circulating tumor cell detection in high risk non-metastatic prostate cancer. J Cancer Res Clin Oncol 2014;140:2157-62.

90. Kolostova K, Broul M, Schraml J, Cegan M, Matkowski R, Fiutowski M, Bobek V. CTCs in localized prostate cancer: isolation, cultivation in vitro and relationship to T-stage and Gleason score. Anticancer Res 2014;34:3641-6.

91. Stott SL, Lee RJ, Nagrath S, Yu M, Miyamoto DT, Ulkus L, Inserra EJ, Ulman M, Springer S, Nakamura Z, Moore AL, Tsukrov DI, Kempner ME, Dahl DM, Wu CL, Iafrate AJ, Smith MR, Tompkins RG, Sequist LV, Toner M, Haber DA, Maheswaran S. Isolation and characterization of circulating tumor cells from patients with localized and metastatic prostate cancer. Sci Transl Med 2010;2:25ra23.

92. Fizazi K, Morat L, Chauveinc L, Prapotnich D, De Crevoisier R,
Escudier B, Cathelineau X, Rozet F, Vallancien G, Sabatier L, Soria JC. High detection rate of circulating tumor cells in blood of patients with prostate cancer using telomerase activity. Ann Oncol 2007; 18:518-21.

93. Murray NP, Reyes E, Fuentealba C, Jacob O. Efficacy of using sequential primary circulating prostate cell detection for initial prostate biopsy in men suspected of prostate cancer. Asian Pac J Cancer Prev 2016;17:3385-90.

94. Murray NP, Reyes E, Orellana N, Fuentealba C, Dueñas R. A comparative performance analysis of total PSA, percentage free PSA, PSA velocity, and PSA density versus the detection of primary circulating prostate cells in predicting initial prostate biopsy findings in Chilean men. Biomed Res Int 2014;2014:676572.

95. Murray NP, Reyes E, Fuentealba C, Orellana N, Morales F, Jacob O. Comparison of the formula of PSA, age, prostate volume and race versus PSA density and the detection of primary malignant circulating prostate cells in predicting a positive initial prostate biopsy in Chilean men with suspicion of prostate cancer. Asian Pac J Cancer Prev 2015;16:5365-70.

96. Murray NP, Reyes E, Fuentealba C, Orellana N, Jacob O, Badilla S. Head to Head comparison of the Montreal Nomagram with the detection of primary malignant circulating prostate cells to predict prostate cancer at initial biopsy in Chilean men with suspicion of prostate cancer. Urol Onc 2015;33:e19-25.

97. Murray NP, Reyes E, Fuentealba C, Orellana N, Jacob O. Primary circulating prostate cells are not detected in men with low grade small volume prostate cancer. J Oncol 2014;2014:612674.

98. Ennis RD, Katz AE, de Vries GM, Heitjan DF, O’Toole KM, Rubin M, Buttyan R, Benson MC, Schiff PB. Detection of circulating prostate carcinoma cells via an enhanced RT-PCR assay in patients with early stage prostate carcinoma. Independence from other pretreatment characteristics. Cancer 1997;79:2402-8.

99. Eschwège P, Moutereau S, Droupy S, Douard R, Gala JL, Benoit G, Conti M, Manivet P, Loric S. Prognostic value of prostate circulating cells detection in prostate cancer patients: a prospective study. $\mathrm{Br} J$ Cancer 2009;100:608-10.

100. Murray NP, Aedo S, Reyes E, Fuentealba C, Jacob O. Outcome of radical prostatectomy in primary circulating prostate cell negative prostate cancer. Ecancermedicalscience 2016;10:671.

101. Meyer CP, Pantel K, Tennstedt P, Stroelin P, Schlomm T, Heinzer H, Riethdorf S, Steuber T. Limited prognostic value of preoperative circulating tumor cells for early biochemical recurrence in patients with localized prostate cancer. Urol Oncol 2016;34:235.e11-6.

102. Murray NP, Aedo S, Fuentealba C, Jacob O, Reyes E, Novoa C, Orellana S, Orellana N. Limited improvement of incorporating primary circulating prostate cells with the CAPRA score to predict biochemical failure-free outcome of radical prostatectomy for prostate cancer. Urol Oncol 2016;34:430.e17-25. 